\title{
St Augustine's Teaching on the Image of God in Man in the Mystery of Creation*
}

\section{Introduction}

The biblical statement about the creation of man in the image and likeness of God (Gen 1:26) indicates first of all God as the One who calls man into existence and gives life to all things. There is also something in this picture that directs our attention to the human being. The image and likeness of God, because we want to discuss them here, are two terms which define the mystery of our humanity. Man created in the image and likeness of God is not only the one who was conceived by God, but also the one who was the only creature that was called into existence in unimaginable closeness with his Creator. He is the only one who was invited to participate in God's life. We are now living in times when it is difficult for people to realize this truth.

The concept of the creation of man in the image and likeness of God is often narrowed down only to the case of the first parents. Meanwhile, this truth also applies to us. Reducing its meaning only to Adam and Eve, sometimes results in forgetting about this truth, and in consequence leads to the complete removal of it from the horizon of our thinking and life. The fact that this is a basic truth and the one, which is crucial for understanding the very nature of a human individual is, as emphasized by the participants of the last Vatican Council (GS 12). Much depends on the proper recognition of the essence of our humanity.

If his understanding is true, then it is much easier to discover the meaning of life assigned to man by the creative plan of God. The origins of the contemporary crisis affecting man himself and his relationship with others have their beginning somewhere in this place. Until we recognize ourselves 
as God's creatures, we will be living in uncertainty and anxiety. Taking up the topic initiated by the Second Vatican Council, we want to take a closer look at the mystery of man created in the image and likeness of God. We want to base our investigations on the doctrine of one of the greatest Doctors of the Catholic Church, Saint Augustine of Hippo. We must, however, point out here that this subject investigated by the Bishop of Hippo, was previously undertaken by L. Krupa ${ }^{1}$.

Considering however, that his latter research work concerned all the works of St Augustine, we decided to consider this topic again, significantly narrowing down the source material. The sources on the basis of which we intend to present the thoughts of the Bishop of Hippo regarding discussed subject, are his three comments on the Book of Genesis ${ }^{2}$ and the treatise On the Trinity ${ }^{3}$. Our intention is to present the Augustinian teaching on the image of God in man in the mystery of Creation. We want to investigate the concept of the human who, among other creatures, is the most important creation of God. It is the creation of man in the image and likeness of God that constitutes his uniqueness ${ }^{4}$. First, we will present the Augustinian vision of man as the image of God, then we will take a closer look at the analogies drawn from the structure of the human soul, which according to Saint Augustine constitute the image of the Holy Trinity.

\section{Man as the Image of God}

The whole universe consists of different kinds of beings. They all owe their existence to God. This is because God is the supreme being. Only God, thanks to the fact that he has the reason of his existence in Himself, is able to create and sustain all beings in existence. Among them, man occupies a special place. Situated somewhere between two worlds, spiritual and material, he enjoys the special respect of God. As the only of God's creatures, he is the representation

Cf. L. Krupa, Obraz Boży w człowieku według nauki świętego Augustyna, Lublin 1948.

2 Augustine, Exegetical writings against Manicheans, PSP vol. 25, Warsaw 1980, (PL 34,173-486).

3 Augustine, On the Trinity, POK vol. 25, Poznań 1963, (PL 42,819-1098).

4 Before we begin to get to know the teaching of Augustine, concerning the creation of man in the image and likeness of God, it is recommended that one reads a good article which presents the achievements of patristic exegesis regarding this subject. Cf. R. Wilson, S. Andrews, The Early History of Exegesis of Gen. 1,26., in: Studia Patristica, 1. Texte und Untersuchungen 63, 1957, 420-437. 
of the living God. It is to this fact, namely the fact of him being created in the image and likeness of God, that man owes his honour and dignity ${ }^{5}$.

However, what legitimizes the elevation of man above the sphere of the animal world is not only the fact that he was created in the image of God, in what this fact finds its very expression. Saint Augustine emphasizes here one more feature that distinguishes man from other creatures, namely a slightly different way, in which human beings were created. Man, like other beings, is the creation of God. In this respect, he is equal to animals and the entire inanimate world. For everything that has been created by the Creator has been called into existence "in the likeness" (per similitudinem) ${ }^{6}$. This similarity is the Only-begotten Son of God7. However, not everything was created - "in the likeness" (ad similitudinem). This way of having origin in the Creator, according to Saint Augustine is reserved exclusively for man: "Not all things, but only this intelligent being was created in the likeness." In connection with the above, the question arises about the quality of God's image in man. If man is the only one created in the image of God and by the one who acts in the most perfect way, what can be said about the perfection of the image, which is present in him? Is it therefore equal to the perfection of the image which is in the Only-begotten Son of God?

The Bishop of Hippo responds to the problem formulated in this way as follows: "By sticking to His ideal and image, we too should not be distancing ourselves from God, because we too are an image of God, although an uneven image, because it was created by the Son in the image of the Father, not born like the Son of God."9 This statement leaves no doubt about the issue that interests us. Augustine states firmly and clearly that there can be no equality here. Man, like the Son of God, is the image of God. However, the image of God in man does not match - in terms of perfection - the image of the Father in the Son. This inequality is based on the origin of Jesus directly from the Father, which is completely different from our origin from Him. In comparison with the Son begotten by the Father, man was only created by God ${ }^{10}$. The Bishop of Hippo

5 Cf. Augustine, On the Trinity XII, XI, 16, 339.0

6 Cf. Augustine, Unfinished Literal Commentary on Genesis XVI, 59, PSP vol. 25, Warsaw 1980, 110, (henceforth: Unfinish.).

7 Cf. Ibid.,XVI, 58, 110; XVI, 61, 111-112.

8 Ibid., XVI, 59, 111. At this point, we have slightly revised the translation by J. Sulowski. In the original, the sentence reads as follows: "Ad ipsam tamen similitudinem omnia non facta sunt, sed sola substantia rationalis." PL 34,243.

9 Augustine, On the Trinity VII, III, 5, 245.

10 Ibid., VII, VI, 12, 256. 
also adds that even the total sinlessness of a human being would not be able to eliminate this inequality ${ }^{11}$.

In the course of further searching for the image of God in man, let us now take a closer look at human nature ${ }^{12}$. St Augustine states that it too was created in the image of God: "And God created man, in the image of God he created him, he created a man and a woman, and blessed them. It is said here that human nature was created in the image of God complementary as both sexes, and the woman is not excluded from what is meant here by the image of God." ${ }^{13}$

In this statement, the Bishop of Hippo cites the words of Genesis (1:27-28), which refer to the creation of man and woman in the image of God. Immediately, however, he refers to the words of the Apostle Paul (1Cor 11: 7), who seems to reserve the position of being the image of God only for the male part of the human race. Could there be any contradiction in the words of Scripture? The problem that arises here, is resolved by our Author as follows: "A woman with her husband is an image of God in such a way that all human nature constitutes one image. However, if a woman is considered to be an additional being, which aim is to serve man, which is a function attributed only to her, then in this sense she cannot be regarded as an image of God. While the image of God is so perfectly and fully represented in a man, in what is specific only to him, like when he and the woman are considered as one image of God." 14

By creating man, God created him as a man and a woman. Despite the diversity of sex in the entirety of human nature, man and woman constitute one human being. Augustine rightly notes that one cannot refuse to grant a woman the status of God's image. Due to the fact of the unity of human nature, she constitutes, together with a man, one, complete image of God. According to the Bishop of Hippo, the right problem only arises when we begin to look at a woman in view of the function, which was granted to her by the creative plan of God. God created a woman as an additional being, whose aim it is to serve man. In this sense, according to the significance of the task that she was granted, she cannot be considered an image of God. This is because due to her pursuit

11 Cf. Unfinish. XVI, 61, 112.

12 This problem, i.e. human nature as a God's image, is completely overlooked by L. Krupa. Cf. L. Krupa, op. cit.

13 Augustine, On the Trinity XII, VII, 10, 335. Cf. also: Augustine, Unfinished Literal Commentary on Genesis III, 22 (34), PSP vol. 25, Warsaw 1980, 163-164, (henceforth: Commentary).

14 Augustine, On the Trinity XII, VII, 10, 335. 
of temporal matters there is a danger of paying attention by her to lower realities and not to the spiritual ones ${ }^{15}$.

The last sentence from the quoted above Augustinian statement also seems to suggest some ontological advantage of a man over a woman. For man is the image of God both when he and woman are one nature, and when he is considered through the prism of what is specific only to him. The final solution to this issue is found in the further part of the Augustinian argument. The Bishop of Hippo states there that "the contemplation of eternal ideas" is available to both men and women ${ }^{16}$. Thus a woman is not excluded from what seems to be the primary occupation of a man. In view of this statement, it would be unreasonable to accuse Saint Augustine of recognizing a woman as a worse or less perfect part of human nature. ${ }^{17}$ When considering the teaching of our Author from the perspective of a dozen or so centuries, we would just like to add that concern for the affairs of this earthy life can also happen to men. This remark in no way diminishes the role of a woman, from the Augustinian perspective, created like a man in the image of God. At this point, it is worth keeping our attention to the polemics of Saint Augustine with the Gnostics regarding the problem of the image of $\mathrm{God}^{18}$. The view emerged in Gnostic circles, according to which the family, i.e. husband, wife and child, should be regarded as an image of the Holy Trinity. In relation to the analysis of human nature as an image of God, carried out above, we would have to add a certain modification of discussed problem here. All this, among others due to the child's figure, which, as can be seen in this example, can cause a lot of trouble not only to parents but also to theologians. Although this opinion of the Gnostics seemed quite unbelievable to Augustine, in De Trinitate we find its exact representation: "According to that opinion, the husband would occupy in a sense the place of God the Father. A child, which has its origin in him by birth would represent the Son. And the third person, corresponding to the Holy Spirit, would be - as they say - a woman who comes from her husband, but is neither his son nor his daughter (Gen. 2:22), although she conceives and gives birth to their offspring."19

The inappropriateness of this manner of thinking can be demonstrated very easily. The greatest difficulty of this analogy is the lack of equality between the individual elements of the triad, which is formed by the father, mother and

Ibid.

Cf. Ibid., XII, VII, 12, 337.

Ibid. XII, VIII, 13, 337.

This theme is also overlooked by L. Krupa. Cf. L. Krupa, op. cit.

Augustine, On the Trinity, XII, V, 5, 331. 
their child. Our author proves this in the following words: "And because it is so, if we were to discover the image of the Trinity not in one human being, but in the following three persons: father, mother and son, then man would not be able to become the image of God before he did not marry his wife, and before the two of them would give birth to the child." ${ }^{20}$ The opinion of Gnostics also contradicts the statement of the Holy Scriptures, which, after all, clearly speaks of creating a single human being in the image of God. There is one more difficulty in all this analogy. For the Holy Spirit is representing the woman who is the wife of her husband and the mother of their son ${ }^{21}$. How then would the Holy Spirit become the mother of the Son of God and the Bride of the Father at the same time? However, it is not possible to explain it on the basis of Christian thought. Let us now turn to the Augustinian anthropology; its analysis will help us to understand the concept of man regarded as the image of God.

According to Saint Augustine, human nature consists of two essential elements: the body and the soul. An illustration of this division is the definition of the man we find in De Trinitate. The Bishop of Hippo states that: "Man is a rational substance composed of soul and body." 22 Among these two elements of human nature, the soul is what is the most perfect aspect of man. One should, therefore, look in it for the image of $\mathrm{God}^{23}$. On the basis of only this statement one could accuse Saint Augustine of extreme Platonism and despising the body. However, this is not the case. The thesis on the creation of man in the image and likeness of God, discussed by us, clearly contradicts this hypothesis. In the thinking of the Bishop of Hippo, it also applies to the body. In three commentaries on the Book of Genesis, Augustine expresses it several times: "However, also our body was created to indicate that we are beings of a higher order than animals, and therefore we are similar to God. For the bodies of all animals, whether living in water or on earth or flying in the air, are inclined to the ground and their position is not upright, as is the body of man." ${ }^{24}$ In the light of the above observations, it can be seen that the upright posture of the human body naturally directs the human towards the sky, towards the spiritual. Thus, it indicates that also in terms of his body, man was created in the image

20 Ibid., XII, VI, 8, 334

21 The main reason for the formulation of this analogy was probably the fact that in the Semitic languages the word "spirit" is feminine.

22 Augustine, On the Trinity, XV, VII, 11, 417.

23 Ibid., XIV, IV, 6, 384.

24 Augustine, On Genesis, Against the Manicheans 1, XVII, 28, PSP XXV, Warsaw 1980, 39. Cf. also: Commentary VI, 12(22), 225. 
of $\operatorname{God}^{25}$. So while one can discern similarity to God in the human body, the concept of creation in the image of God refers, in fact, only to the soul. For man is an image of God: "...only in terms of the intelligent soul who can be a place of cognition of God." ${ }^{26}$ Augustine refers to the concept of mind or reason when describing this intelligent soul ${ }^{27}$. We must note here that in Augustinian anthropology reason has been granted two functions. The first is focused on dealing with temporal matters, while the second has eternal things as the object of its action $^{28}$. The duality that arises here is based, however, in another distinction that our Author made in relation to man. While maintaining the internal unity of man, Saint Augustine distinguished in him two aspects, namely the "outer man" and "inner man." ${ }^{29}$ According to this division, "outer man" is the one who achieves knowledge of the material world. By contrast, the knowledge of eternal truths is attributed by the Bishop of Hippo to "the inner man." Thanks to these distinctions, we can now precisely define the concept of God's image. Following Saint Augustine one should state here that what constitutes it is the nature of the whole human soul. In the strict sense, however, one is legitimated to speak about God's image only in relation to this "part" of the soul, whose action concerns the contemplation of eternal things: "According to what we have previously said about the nature of the human soul, if the whole soul is engaged in the contemplation of the truth, then it can be - in its all entirety - considered the image of God. And when there is a division in it and some part of its attention is directed to the activity in the field of temporal matters, then it constitutes image of God only in the part that contemplates the truth, not in the one which is preoccupied with action and matters of lesser importance."30

\section{Analogical Image of the Holy Trinity in the Soul}

Saint Augustine tried to look for manifestations of the Holy Trinity in all creation. However, strictly speaking, the most complete trace of the Trinity exists in man. Only man carries in himself the image of the living God. This image is the image of the Holy Trinity. It was this reality, the trinitarian character

Cf. Unfinish. XVI, 60, p. 111.

26 Augustine, On the Trinity XII, VII, 12, 336. Cf. also Ibid., XIV, IV, 6, 384.

27 Ibid., XV, I, 1, 407.

28 Ibid., XII, III, 3, 330.

29 Cf. Ibid., On the Trinity, XII, I, 1, p. 328.

30 Ibid., XII, VII, 10, 335. Cf. also Ibid., XII, IV, 4, 331. 
of God's image, which Augustine tried to emphasize through various analogies which he discovered in human nature. Therefore, following his idea, we now want to proceed investigation of the analogous image of the Holy Trinity in the soul.

\section{Triad: Soul, Knowledge, Love}

The first triad proposed by the Bishop of Hippo is made up of: soul, knowledge and love $e^{31}$. The starting point for this analogy is the analysis of the idea of love, in which Augustine distinguished three realities. They are: 1) a loving subject, 2) the object of his love, 3) love ${ }^{32}$.

Our author is primarily interested only in the special instance of this process. It is about a situation in which a loving person loves him/herself. The one who loves is, therefore, identified with the object of his/her love. And if so, then it makes no sense to say that someone loves him/herself and is loved by him/herself, because these two realities can be reduced to one in this situation. All this reasoning of Saint Augustine sums up in the following way: "So there are two things when one loves him/herself: love and the object of his/her love. For then the loving subject and the object of his loves constitute one being. Thus, not always love must be accompanied by those three things." 33

After concluding this analysis, the Bishop of Hippo focuses his attention on the soul itself, in order to seek God's image in its depths. If the soul loves itself, then according to the above reasoning, we then have two things: soul and love. When we then assume that love is a spiritual substance, then we will also have to admit that along with the soul it constitutes certain unity: "So when they refer to each other, they are two of them; but when one make absolute statements about each of them individually, each of them is a spirit, and both are one spirit, and each is a soul, and both constitute also one soul." ${ }^{34}$ The soul and love do not however create the triad only by themselves.

Augustine is, thus, forced to proceed further. In order to do that, he also analyzes the idea of love and notes that: "The soul cannot love itself if it does not know itself. Because how can you love without knowing what is the

31 At this point, it is worth noting that already in Confessions the notion of a triad occurs, which previously caught the attention of Saint Augustine, which is different than the one we present at present. It was a triad of being, cognition and will. Cf. Augustine, Confessions XIII, II, Warsaw 1987, 344.

32 Cf. Augustine, On the Trinity, IX, II, 2, 279.

33 Ibid., IX, II, 2, 279.

34 Ibid., IX. II, 2, 280. 
object of who you love." ${ }^{35}$ We see, then, that the soul's love for itself depends on its self-knowledge. If the soul does not know itself, it also cannot love itself. Knowledge, therefore, appears here as a condition of love. In order to provide closer insight of the whole problem, Augustine analyzes the process of cognition, as he did earlier in the case of love. Here, too, he is primarily interested in the soul and in the way it is achieving knowledge of itself. Carefully carried out argument ends with the following conclusion: "So just as the soul through the senses of the body collects information about bodily things, it also collects information about non-corporeal things - through itself. Therefore, the soul recognizes itself through itself because it is immaterial." ${ }^{36}$ Now we can conclude that we have discovered the whole triad. It consists of: soul, cognition and love. "And so: the soul itself, its love and cognition are three things, and all three are one, and when they are perfect, they are equal." ${ }^{37}$

At this point of the analysis of Augustinian thought the problem of relations that occur between soul, cognition and love, already arises. According to Saint Augustine, these three elements are one. In addition, they can be equated with one another. Our author, however, makes such an option dependent on the perfection of each of these elements. However how should one understand the perfection to which Saint Augustine refers here? Well, in the view of Bishop of Hippo, perfection here consists in acting in accordance with the nature of a given being. Therefore, according to this approach, the soul should not love itself neither less nor more than it is implied by its nature. Its love will not be perfect if it loves herself, just as it loves its body. Nor should it love itself with love, which is reserved only for $\operatorname{God}^{38}$. The same is the case with the cognition of the soul. It can be considered perfect only in case when the soul gets to know itself, i.e. when it is the only and complete object of its cognition. Only then is the concept of the soul equal to itself, i.e. it is neither lower nor higher than it $^{39}$.

However, we need to mention here a certain reservation that Saint Augustine himself expresses. All this reasoning becomes acceptable, when we carry out our investigations in ontological terms. Namely, this triad can be regarded as the image of the Holy Trinity only when we attribute the status of the substance both to cognition and love. Love and cognition are not the powers of the soul here, which would be rooted in it like in a subject. However, they

35 Ibid., IX, III, 3, 280.

36 Ibid., IX, III, 3, 280-281.

37 Ibid., IX, IV, 4, 281.

38 Cf. Ibid., IX, IV, 4, 281.

39 Cf. Ibid. 
exist substantially, just like the soul does ${ }^{40}$. Nevertheless, with regard to this approach, a new problem immediately arises, which concerns the coexistence of these three elements. Is it possible to reconcile their separateness with their unity? Seemingly, it might seem that we have found ourselves in hopeless situation. However, it is not the case. The whole issue is self-resolved when Augustine notices that these three parts of our triad are of the same nature: "But I do not see why these three elements of the soul would not be of the same substance, since the soul loves itself and knows itself, this is also the nature of these three things, that the soul in no other way can be loved or known. So these three things must be one and the same nature. If they were a mixture, they would not be three things and they could not stay in relation to each other."41

The aforementioned remark about the unity of nature: soul, cognition and love allows the Bishop of Hippo to proceed to further explanation of their mutual co-existence. Since our author states that each of these three realities: "...exists in itself, and yet they also exist in each other, each of them exists in its entirety in the other two and two of them in their entirety exist in each one individually. And so each of them exist in each other and in all of them." ${ }^{42}$ These three elements thus remain a trinity without any confusion, although they also create certain unity. Admittedly, each of them is a substance, while taken together, they all are one substance and a being, because they are in a mutual relationship ${ }^{43}$. In view of what we have said above, it can be stated that between the soul, its cognition and its love, assuming that they are perfect, there are relations of equality and mutual interpenetration.

\section{Triad: Memory, Intellect, Will}

The next triad, in which one can discern the image of God, is constituted by: memory, intellect and will. Unlike the previous one, as the Bishop of Hippo notices later, this one is more distinctive in its nature ${ }^{44}$. We need, however first, to indicate here, that this next triad does not constitute a completely abstract new concept in the whole thought of Saint Augustine. It is simply the result of a more thorough and insightful analysis of the very same issue ${ }^{45}$. In the course 
of a closer analysis of this problem, it can be seen in the approach of Bishop of Hippo, the unique style of thinking about the Holy Trinity, which is characteristic of the thought of Western Church ${ }^{46}$. Before our Author begins to discuss the individual powers of the soul, he first emphasizes their unity: "These three things" - memory, intellect, will - "are one, not three lives; they do not form three souls, but they are one soul; and so they are not three substances, but one substance." 47

So we can say, following Saint Augustine, that these three powers not only co-exist, but also contain each other, thanks to the equality between them: "And if they were not equal, not only individually among themselves, but also if each of them separately was not equal to all of them together, and if they all together were not equal to each one of them individually, then they could not contain each other. Because not only are they contained in each, but also all of them are contained in each one individually." ${ }^{38}$ The essential component of this triad is memory, or more specifically, the soul's memory of itself ("memoria sui"). It is the basis for the entire process that takes place in the soul. It allows one not only to recall events that took place a long time ago. Thanks to the memory, the soul can also be present for itself. Thus, the memory of ourselves is what we would today call the sense of identity: "That is why, as in the case of past events, we define memory as the power to remember them and to recall them through a reminder. Analogically, when it comes to this presence of the soul for itself, one can, without falling into ridiculousness, call the memory power that allows the soul to be present for itself, so that it can understand itself with its own thought, and thanks to the love directed towards itself, connect the memory with understanding." 49

Thus, as we can see, memory concerns both past things and what is happening in the present. It allows the soul to have insight in itself. It is what shapes the sight of thoughts. ${ }^{50}$ Because of it, "because the soul perceives itself in an intellectual way, it understands and recognizes itself, so it gives rise to understanding and self-cognition. Indeed, one perceives a non-corporeal reality

46 Western theological reflection regarding the Holy Trinity, begins its investigations from considering one divine being, to finally conclude the considerations with the establishing the separation of the three divine Persons. Cf. J. Kelly, The Origins of Christian Doctrine, Warsaw 1988, 191-210.

47 Augustine, On the Trinity, X, XI, 18, 307.

48 Ibid., X, XI, 18, 308.

49 Ibid., XIV, XI, 14, 394-395.

50 Cf. Ibid., XIV, VI, 8, 387. 
by understanding it and one achieves its cognition by its understanding. Not in this way, however, the soul gives birth to the knowledge of itself, as if it were unknown to itself before. On the contrary, it already knew itself, just as there are known things present in memory, even when you do not, actually, think about them." ${ }^{51}$ The cognition that Saint Augustine mentions here comes from memory. Thanks to it, the soul is aware of itself. It knows the fact that it is a soul and that is why it can seek to know itself. It does it with its entire being, because only the whole soul in its entirety can achieve knowledge of anything ${ }^{52}$.

Here the second constitutive element of the Augustinian triad appears: intelligence, which is defined by the Bishop of Hippo as follows: "By intelligence I mean in this case the actual cognition, this is the discovery of ideas present in the memory that the soul has not thought of before, thanks to which our thought takes a certain form. ${ }^{53}$ In this triad, which we present here, in contrast to the previous one, there is a certain dynamics. The second part of this analogy has its origin in soul.

Namely, as a result of thinking, the soul gives rise to knowledge of itself, its inner word ${ }^{54}$. This knowledge is closely related to love: "When the soul knows and loves itself, then its word connects with it through love. And because it loves its own knowledge and it knows love, then the word is contained in love, and love in contained in the word, and both are contained in the soul who loves itself and expresses itself." ${ }^{\prime 5}$ In this way, together with the Bishop of Hippo, we have discovered in our souls another triad, which is the image of God. The two first components presented above are connected by a third, i.e. love, which is an expression of the activity of will. Therefore, the will is what unites the soul and the word that was created through it ${ }^{56}$.

At this point, however, we must mention a key important remark by Saint Augustine. According to him, this triad of memory, intellect and will is the image of God, not because the soul can remember, understand and love itself. Admittedly, the basis of its being an image of God lies much deeper. Our author sees it in the fact that the soul can remember, understand and love the very creator who has placed life in it ${ }^{57}$. If only the soul does it, then it becomes

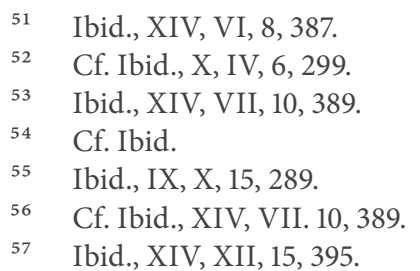


wise. As we mentioned above, this triad is more dynamic than the first one, since it demonstrates a certain process that takes place in the soul. In these life activities that constitute this process one can see an analogy with the inner life of the Holy Trinity. In this way, the relation of memory to the intellect represents in this triad the image of the relation of the Father to the Son. On the other hand, by combining the relation of fatherhood and giving birth, the will, in this way, represents the very image of the Holy Spirit ${ }^{58}$.

However, despite the similarity that can be seen here, Saint Augustine is aware of the great difference between the Holy Trinity and its created image $^{59}$. First of all, it should be said that these three elements of our triad are characterized by a distinctiveness of their action. However, this is not the case with regard to the Holy Trinity, since the three Persons of the Holy Trinity always act together. Their action is one ${ }^{60}$. Next, it should be noted that the above mentioned three powers of man are a kind of human abilities. Though they are the best human qualities, they cannot be considered human per se. Again, we must admit that this is not the case with regard to the Holy Trinity. For the entire Trinity is nothing but one God. God is an infinitely simple being ${ }^{61}$. Eventually what clearly determines the difference between the Holy Trinity and its image is the number of persons. In the image of the Trinity, we have one Person, while in the Holy Trinity there are three Persons. In spite of this fact, there is greater inseparability in the Holy Trinity than in the triad constituting one human person ${ }^{62}$.

\section{Conclusion}

Three comments on the Book of Genesis and the treatise On the Trinity enabled us to become acquainted with the Augustinian teaching on the image of God in man in the mystery of Creation. Thanks to such a narrowing of the source material, we could more carefully and with greater prudence analyze the thoughts of the Bishop of Hippo. We hope that in this way we managed to avoid the risk of superficiality and we took into account all the statements of Saint Augustine regarding the problem posed. Unfortunately, L. Krupa did not prevent himself

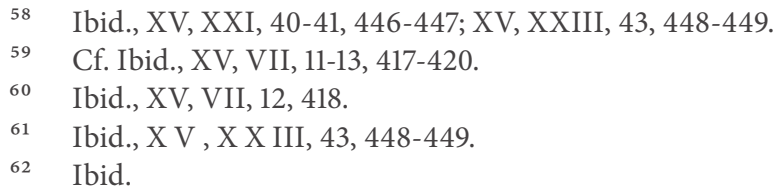


from committing this mistake ${ }^{63}$. He did not take up the subject of human nature as an image of God, and completely passed over in silence the polemics of the Bishop of Hippo with Gnostics, who regarded the human family as the image of the Holy Trinity. Based on the analysis carried out, we could see that according to Saint Augustine's image of God in man is to be sought in his soul, and in the strict sense, in this "part" of him, which is focused on the contemplation of eternal ideas. The essence of the image of God is expressed in the ability of the soul to participate in God's life. All this reflects, as Saint Augustine states, the true honour and dignity which man owes to his Creator. A characteristic feature of God's image, even a basic one - in view of the Augustinian approach - is its trinitarian character.

Saint Augustine tried to seek the traces of the Holy Trinity everywhere. This significant task was the passion of his life. Finally, he has found the image of the Holy Trinity in man. He tried to provide his readers with an insight into this reality through the trinitarian analogies, the source of which he discovered in the structure of the human soul. Considering the entirety of St. Augustine's teaching on the image of God in man in the mystery of Creation, the analogous images of the Holy Trinity in the soul seem to be the most interesting for us. On the other hand, like Saint Augustine, however, we are aware of their great limitations. For what is created, even in its most beautiful representation, in comparison with the Creator will always be in a vulnerable and poor condition.

63 Cf. L. Krupa, op. cit. 